УДК 637.5:636.087.7

Л.А. Зубаирова, И.Р. Фахретдинов, Р.С. Исхаков

БИОЛОГИЧЕСКАЯ ЦЕННОСТЬ, ФУНКЦИОНАЛЬНО-ТЕХНОЛОГИЧЕСКИЕ СВОЙСТВА МЯСА И ЖИРА БЫЧКОВ ПРИ СКАРМЛИВАНИИ КОРМОВОГО КОНЦЕНТРАТА

\footnotetext{
Ключевые слова: говядина; биологическая ценность; функционально-технологические свойства; белково-качественный показатель.
}

Введение. Мясная промышленность - это крупная отрасль пищевой индустрии России, которая обеспечивает производство основного продукта питания - мяса и его производных.

В перерабатывающей отрасли основная доля себестоимости готовой продукции приходится на сырье животного происхождения, от качества которого зависит и непосредственно качество готовой продукции. Среди показателей качества необходимо отметить, прежде всего, производственные: возраст, порода, здоровье животного и птицы, условия содержания и откорма, вид транспортировки, которые обуславливают его пригодность к переработке. При этом совершенствование технологий интенсивного выращивания и откорма молодняка сельскохозяйственных животных остается приоритетным направлением исследований в целях увеличения производства мяса.
Эффективным методом увеличения количества и улучшения качества продуктов животноводства и птицеводства является повышение полноценности кормления животных и птицы за счет высокобелковых кормов и различных современных кормовых добавок, которые оказывают комплексное положительное воздействие на обменные процессы, регулируют гормональный и иммунный статус животного и птицы [2$7,9,10]$.

В связи с этим целью работы явилось исследование биологической ценности и свойств мяса и жира при включении в рационы животных нового кормового концентрата «Золотой Фелуцен».

Объекты, материалы и методы исследований. Для проведения исследований были отобраны 4 группы 6-месячных бычков черно-пестрой породы по 15 голов в каждой (контроль и опыт - I, II, III). В рационы молодняка опытных 


\section{DOI: 10.31563/1684-7628-2018-45-1-77-80}

групп (I, II, III) включали комбикорм, содержащий протеино-углеводно-витаминно-минеральный кормовой концентрат «Золотой Фелуцен» в дозировке 50; 75 и 100 г в 1 кг соответственно.

По завершении научно-хозяйственного опыта был проведен убой трех бычков из каждой группы, достигших 18-месячного возраста. После первичной переработки и разделки туш по действующим технологическим инструкциям для проведения исследований были отобраны образцы мяса и жира.

Физико-химические показатели и функционально-технологические свойства изучались по общепринятым методикам [1]: содержание влаги в образцах путем высушивания навески до постоянной массы при температуре $150 \pm 2{ }^{\circ} \mathrm{C}$; содержание белка - методом Кьельдаля с последующим фотометрированием проб; содержание жира - экстрагированием сухой навески эфиром в аппарате Сокслета. Для расчета биологической ценности мяса определяли содержание триптофана по методу В. Вербицкого и Д. Детериджа и оксипролина по методу М.А. Логана и Р.Е. Неймана в модификации Т.Ф. Красильниковой и др., $\mathrm{pH}$ - потенциометрически в водной мясной вытяжке, влагоудерживающую способность - по методу Р.М. Салаватулиной; йодное число и температуру плавления жира - согласно рекомендациям [8]. Энергетическую ценность мяса определяли расчетным путем по формуле В.А. Александрова.

Результаты исследований. Значимость мяса состоит в его высокой пищевой и биологической ценности.

Для изучения влияния кормовой добавки «Золотой Фелуцен» на биологическую ценность мяса были рассчитаны белково-качественные показатели (БКП) по соотношению в мышечной ткани двух аминокислот - триптофана и оксипролина.

Как известно, все мышечные белки содержат триптофан, а в соединительнотканных белках он отсутствует. Чем больше отношение триптофана к оксипролину, тем лучше качество мясного сырья.

Исследования показали, что высоким содержанием триптофана отличалось мясо, полученное от молодняка опытных групп. Так, мясо бычков контрольной группы уступало по содержанию триптофана говядине, полученной от животных опытных групп, на 12,1; 23,7 и 20,9 мг \% соответственно. По содержанию оксипролина отмечается незначительное превосходство контрольной группы (таблица 1).

Таблица 1 Биологическая ценность и функционально-технологические свойства длиннейшей мышцы спины бычков

\begin{tabular}{|l|c|c|c|c|}
\hline \multirow{2}{*}{\multicolumn{1}{|c|}{ Показатель }} & \multicolumn{3}{c|}{ Группа } \\
\cline { 2 - 5 } & контроль & опыт I & опыт II & опыт III \\
\hline Триптофан, мг \% & $384,6 \pm 9,21$ & $396,7 \pm 11,23$ & $408,3 \pm 8,72$ & $405,5 \pm 10,48$ \\
\hline Оксипролин, мг \% & $61,4 \pm 4,32$ & $60,6 \pm 3,64$ & $60,4 \pm 4,22$ & $60,2 \pm 3,48$ \\
\hline Белково-качественный показатель & 6,26 & 6,54 & 6,76 & 6,73 \\
\hline рН & $5,65 \pm 0,02$ & $5,49 \pm 0,05$ & $5,44 \pm 0,04$ & $5,53 \pm 0,03$ \\
\hline Влагоудерживающая способность, \% & $63,81 \pm 0,32$ & $64,39 \pm 0,27$ & $64,80 \pm 0,25$ & $64,62 \pm 0,21$ \\
\hline Увариваемость, \% & $32,32 \pm 0,14$ & $31,97 \pm 0,11$ & $31,56 \pm 0,16$ & $31,64 \pm 0,21$ \\
\hline КТП & 1,97 & 2,01 & 2,05 & 2,04 \\
\hline
\end{tabular}

Следует отметить, что в целом белково-качественные показатели мяса во всех оцениваемых группах имели довольно высокие значения: 6,26-6,76 ед., что свидетельствует о высокой биологической ценности говядины, полученной при убое подопытных животных.

Важным показателем при оценке мяса является величина $\mathrm{pH}$, которая влияет на органолептические показатели, влагосвязывающую способность и стойкость при хранении.

При определении показателя $\mathrm{pH}$ мяса выявлено, что во всех группах значение примерно на одном уровне: 5,44-5,65. Такие показатели являются оптимальными и отражают желаемое течение послеубойных процессов в туше.

При качественной оценке мяса наряду с физико-химическими показателями принято опре- делять функционально-технологические свойства, главные из которых - влагоудерживающая способность и увариваемость.

Исследования показали, что лучшими функционально-технологическими свойствами обладали образцы мяса, полученного от животных опытных групп. Так, показатель влагоудерживающей способности был выше в мясе опытных групп на $0,58-0,99 \%$, а показатель увариваемости в мясе опытных групп был ниже на 0,35$0,76 \%$ по сравнению с контролем.

Кулинарно-технологический показатель (КТП) мяса бычков контрольной группы ниже образцов опытной группы на 2,$0 ; 3,9$ и 3,4 \% соответственно (таблица 1).

В целом установлено, что мясо животных всех опытных групп, получавших с рационом 
кормовой концентрат «Золотой Фелуцен», обладало высокими функционально-технологическими свойствами.

Многочисленными исследованиями установлено, что количество и химический состав жировой ткани находится в прямой зависимости от породы, пола, возраста, живой массы, условий содержания, а также от полноценности кормления.

Для оценки качества жировой ткани в зависимости от скармливания бычкам различных доз кормовой добавки изучен химический состав этой ткани (таблица 2).

Результаты исследования показали, что состав и свойства жировой ткани у подопытных бычков отличались. Содержание сухого вещества в жире молодняка опытных групп по сравнению с контролем было выше на 0,21-0,30 \%. Причём это увеличение происходило за счёт повышения удельного веса собственного жира. По количеству собственного жира в жировой ткани контрольный образец уступает опытным, полученным от откормленных бычков I, II и III опытных групп на 0,$24 ; 0,38$ и 0,30 \% соответственно.
Известно, что жир является смесью триглицеридов с примесями фосфатидов, стеридов, витаминов, пигментов, азотистых веществ и воды. Свойства триглицеридов определяются составом и соотношением входящих в них жирных кислот. Наибольшее значение для организма человека имеют ненасыщенные жирные кислоты (олеиновая, линоленовая и арахидоновая), которые участвуют в жировом обмене и играют важную роль в нормализации холестеринового обмена. Они не синтезируются в организме человека и должны доставляться с пищей. Чем больше в жире насыщенных кислот, тем жир тверже и тем ниже его усвояемость. Насыщенные жирные кислоты характеризуются высокими показателями температур плавления и застывания, а ненасыщенные имеют высокие показатели йодного числа, низкую температуру плавления и застывания [8].

Жир-сырец бычков опытных групп имел температуру плавления ниже на $0,40{ }^{\circ} \mathrm{C}$ в I группе, на $0,70{ }^{\circ} \mathrm{C}$ - во II и на $0,60{ }^{\circ} \mathrm{C}-$ в III группе, чем у контрольного молодняка.

По энергетической ценности жир опытных бычков превосходил контроль на 0,88-0,91 МДж.

Таблица 2 Химический состав и свойства жировой ткани

\begin{tabular}{|l|c|c|c|c|}
\hline \multirow{2}{*}{ Показатель } & \multicolumn{3}{c|}{ Группа } \\
\cline { 2 - 5 } & контроль & опыт I & опыт II & опыт III \\
\hline Влага, \% & $10,34 \pm 1,02$ & $10,13 \pm 0,93$ & $10,04 \pm 0,98$ & $10,08 \pm 0,98$ \\
\hline Сухое вещество, \% & $89,66 \pm 1,02$ & $89,87 \pm 0,93$ & $89,96 \pm 0,98$ & $89,92 \pm 0,98$ \\
\hline Белок, \% & $2,06 \pm 0,06$ & $1,96 \pm 0,08$ & $1,92 \pm 0,05$ & $1,93 \pm 0,07$ \\
\hline Жир, \% & $87,48 \pm 0,87$ & $87,72 \pm 0,79$ & $87,86 \pm 0,84$ & $87,78 \pm 0,67$ \\
\hline Энергетическая ценность 1 кг, МДж & 34,45 & 35,33 & 35,36 & 35,34 \\
\hline Йодное число, \% йода & 29,12 & 29,27 & 29,48 & 29,41 \\
\hline Температура плавления, ${ }^{\circ} \mathrm{C}$ & 44,5 & 44,1 & 43,8 & 43,9 \\
\hline
\end{tabular}

Выводы. Скармливание бычкам кормового концентрата «Золотой Фелуцен» оказало положительное влияние на биологическую ценность, функционально-технологические свойства мяса и качество внутреннего жира-сырца.

\section{Библиографический список}

1. Антипова, Л.В. Методы исследования мяса и мясных продуктов [Текст] / Л.В. Антипова, И.А. Глотова, И.А. Рогов // М.: Колос, 2001. $376 \mathrm{c}$.

2. Камильянов, А.А. Использование пробиотика Витафорт при выращивании ягнят [Текст] / А.А. Камильянов, Ф.С. Хазиахметов // Наука и образование в XXI веке: сборник научных трудов Междунар. научно-практ. конф. Ч. 30. Тамбов: Бизнес-Наука-Общество, 2013. C. 64-65.

3. Камильянов, А.А. Рост и развитие ягнят при использовании пробиотика Витафорт [Текст] / А.А. Камильянов, Ф.С. Хазиахметов // Вестник Башкирского ГАУ. 2014. № 4. С. 54-56.
4. Нугуманов, Г.О. Пробиотик Витафорт в рационах поросят-отъёмышей [Текст] / Г.О. Нугуманов, Ф.С. Хазиахметов // Известия Самарской ГСХА. 2012. № 1. С. 162-164.

5. Тагиров, Х.Х. Мясная продуктивность бычков при включении в их рацион кормового концентрата «Фелуцен» К-6 [Текст] / Х.Х. Тагиров, И.М. Зиннатуллин, Е.Н Черненков // Молочное и мясное скотоводство. 2016. № 3. С. 1719.

6. Тагиров, Х.Х. Продуктивные качества быков при включении в их рацион пробиотика [Текст] / Х.Х. Тагиров, Г.М. Долженкова, И.Ф. Вагапов // Молочное и мясное скотоводство. 2016. № 6. С. 26-27. 
7. Тагиров, Х.Х. Мясная продуктивность быков при вскармливании биодобавки биодарин [Текст] / X.X. Тагиров, Г.М. Долженкова, И.Ф. Вагапов // Зоотехния. 2015. № 7. С. 2526.

8. Тагиров, Х.Х. Физико-химические и биохимические основы производства мяса и мясных продуктов [Текст]: учеб. пособие / Х.Х. Тагиров, М.Б. Ребезов, Б.К. Асенова и др. Алматы, 2015. 215 с.

9. Тагиров, Х.Х. Мясные качества и биологические особенности бычков и кастратов разного происхождения [Текст] / X.X. Тагиров,
Л.А. Гильмияров // Главный зоотехник. 2012. № 1. С. 32-40.

10. Хазиахметов, Ф.С. Диетические корма, ароматические и вкусовые добавки при выращивании молодняка сельскохозяйственных животных [Текст]: практическое руководство / Ф.С. Хазиахметов, Б.Г. Шарифянов, Р.Р. Гадиев и др.; Министерство сельского хозяйства Республики Башкортостан, Башкирский государственный аграрный университет, Башкирский научно-исследовательский институт сельского хозяйства, Закрытое акционерное общество «Экопрод». Уфа, 2006. 36 с.

\section{Сведения об авторах}

1. Зубаирова Лилия Альбертовна, канд. техн. наук, доцент кафедры технологии мяса и молока, ФГБОУ ВО Башкирский ГАУ, г. Уфа, ул. 50-летия Октября, 34, e-mail: lilija14@mail.ru.

2. Фахретдинов Ильдар Руфкатович, старший преподаватель кафедры технологии общественного питания и переработки растительного сырья, ФГБОУ ВО Башкирский ГАУ, г. Уфа, ул. 50-летия Октября, 34, e-mail: thppr13@mail.ru.

3. Исхаков Ришат Сальманович, канд. с.-х. наук, доцент кафедры технологии мяса и молока, ФГБОУ ВО Башкирский ГАУ, г. Уфа, ул. 50-летия Октября, 34, e-mail: irs1956@mail.ru.

Выявлено положительное действие протеино-углеводно-витаминно-минерального кормового концентрата «Золотой Фелуцен» на формирование показателей биологической ценности и функционально-технологических свойств мяса и жира молодняка крупного рогатого скота.
Полученные данные позволяют создать практическую основу для обоснования использования кормового концентрата «Золотой Фелуцен» при выращивании молодняка крупного рогатого скота, поскольку он обеспечивает высокий уровень качества получаемой продукции.

L. Zubairova, I. Fahretdinov, R. Iskhakov

\section{MEAT AND FAT BIOLOGICAL VALUE, FUNCTIONAL AND TECHNOLOGICAL PROPERTIES OF BULL CALVES FED WITH FODDER CONCENTRATE}

\section{Key words: beef; biological value; functional and technological properties; protein quality index.}

\section{Authors' personal details}

1. Zubairova Liliya, Candidate of technical sciences, assistant professor of the Meat and Milk Technology department, Federal State Budgetary Educational Institution of Higher Education «Bashkir State Agrarian University», Ufa, 50-letya Oktyabrya St., 34, e-mail: lilija14@mail.ru.

2. Fahretdinov Ildar, senior teacher of the Public Catering and Plant Raw Materials Technologies department, Federal State Budgetary Educational Institution of Higher Education «Bashkir State Agrarian University», Ufa, 50-letya Oktyabrya St., 34, e-mail: thppr13@mail.ru.

3. Iskhakov Rishat, Candidate of agricultural sciences, assistant professor of the Meat and Milk Technology department, Federal State Budgetary Educational Institution of Higher Education «Bashkir State Agrarian University», Ufa, 50-letya Oktyabrya St., 34, e-mail: irs1956@mail.ru.

The present paper reveals a positive effect of protein-carbohydrate-vitamin-mineral fodder concentrate «Zolotoi Felutsen» on development of meat and fat biological value as well as its functional and technological properties.
The resulted data found a practical basis to prove advantages of fodder concentrate «Zolotoi Felutsen» in rearing bull calves for providing a high level quality of finished products.

(C) Зубаирова Л.А., Фахретдинов И.Р., Исхаков Р.С. 